\title{
Influence of Family Ownership on Earnings Quality
}

\author{
Sang-Ho Kim and Yohan An*
}

\begin{abstract}
Manuscript type: Research paper

Research aims: This paper investigates how family ownership affects firm's earnings quality. The focus is on firms listed on the Korean Stock Exchange (KSE).

Design/Methodology/Approach: This study uses panel data to classify family ownership into two categories: pure family ownership and ownership-control disparity (wedge) where wedge is further divided into 1) wedge ratio and 2) wedge multiplier. In addressing the category of ownership-control disparity, it is important to measure how much control rights are greater than ownership rights. Therefore, this study employs the wedge multiplier to overcome the limitation of not separating management control and ownership. Firms' earnings quality is tested by using four proxies proposed by Jonas and Blanchet (2000): 1) persistence, 2) value relevance, 3) conservatism, and 4) accruals quality.

Research findings: This research finds family ownership to be positively associated with earnings quality, value-relevance and accruals quality. However, ownership-control disparity does not reduce the earnings quality. This finding is not consistent with previous studies. Thus, it is deduced that the controlling family shareholders of the chaebol firms have a dominant influence on firms which they invested in by using affiliated ownership. Significant ownership-control disparity is prevalent in chaebol firms, resulting in low earnings quality.
\end{abstract}

\footnotetext{
Sang-Ho Kim is a Lecturer at the International Business School Suzhou (IBSS), Xi'an JiaotongLiverpool University (XJTLU), China. Email: Sangho.Kim@xjtlu.edu.cn

* Corresponding author: Yohan An is an Assistant Professor at the Department of Finance \& Accounting, College of Business Administration, Tongmyong University, Republic of Korea. Email: accahn@tu.ac.kr
}

https://doi.org/10.22452/ajba.vol12no2.3 
Theoretical contribution/Originality: Family ownership is predominant in a number of countries, especially in East-Asian countries. In that regard, this study is important. It contributes to the understanding of family ownerships and firms' earnings quality not only for the Korean contexts, but also for other East Asian countries.

Research limitation/Implications: The four proxies of earnings quality used in this study do not necessarily reflect all aspects of the earnings quality. In this study, the results between family ownership and earnings quality are mixed. The results based on the association between corporate governance and earnings quality could be attributed to the way earnings quality is defined. The management of the chaebol firms or large business groups should try to improve transparency and the quality of their financial reporting.

Keywords: Chaebol, Earnings Quality, Family Ownership, Panel Data, Wedge

JEL Classification: G32, G34, M41

\section{Introduction}

Family-owned firms are a common business structure throughout the world, including in countries with well-developed corporate governance. In general, most public firms are owned, controlled and managed by family shareholders who are also the founders and future heirs of the companies (Shleifer \& Vishny, 1986; La Porta, Lopez-deSilanes, \& Shleifer, 1999). Publicly traded firms in more than half of East Asian corporations are family controlled (La Porta et al. 1999) and 30 per cent of the S\&P 500 in the US is a family firm (Anderson \& Reeb, 2003). According to the Korea Economic Research Institute (2016), 62 per cent of firms in Korea are managed by the controlling family, and an average of 33.5 per cent shareholdings are controlled by family and affiliated firms.

However, there are some studies which show conflicting results on the role of family ownerships. The interest alignments hypothesis for family ownership states that, as the ownership level increases, the family ownership and other shareholders' interests become aligned, and the management makes more efforts into maximising the shareholders' wealth. In contrast, the entrenchment hypothesis for family ownership suggests that the family ownership could try to maximise its wealth against the interests of the minority shareholders when the ownership is considered to be the dominant or controlling power. 
Specifically, East Asian studies of controlling and family ownership apply the entrenchment hypothesis, such that the greater the difference is between control rights and ownership (ownership-control disparity), the greater the effect of entrenchment of the controlling family ownership. This makes the large ownership-control disparity reduces firm value and firm performance (La Porta et al., 1999; La Porta, Lopezde-Silanes, Shleifer, \& Vishny, 2000; Claessens, Djankov, \& Lang, 2000; Lemmon \& Lins, 2003). Among East Asian countries, the agency problem, which is noted by the difference between the controlling family shareholders, and the minority shareholders, is an outstanding phenomenon. It shows the difference between voting rights and cash flow rights, known as wedge or ownership-control disparity. Lemmon and Lins (2003) investigated the ownership structure of eight East Asian countries. They found that controlling families have twice as much control power over their own ownership than other forms of ownership. This is especially so in Singapore, where the difference between control and ownership is three times above the normal rate. This form of ownership structure that exists among East Asian countries, including Korea, carries certain features. Among these is that the controlling family shareholders exercise huge control rights over their cash flow rights. The controlling shareholders, usually the founder and his/her family members, tend to play a dominant role in the decision-making process, particularly in Korean firms. This is accomplished through a chain of ownership relations called pyramidal ownerships (Lim \& Kim, 2005). It allows the controlling families to have immense control at all levels of the management, making it easier to expropriate the minority shareholders (Claessens et al., 2000; Claessens, Djankov, Fan, \& Lang, 2002; Fan \& Wong, 2002).

The business groups (so-called chaebol) ${ }^{1}$ in Korea which are controlled by families, and the controlling families have a huge managerial power over the whole group despite their small fraction of shareholdings, which may be as low as 10 per cent (Jung \& Kwon, 2002). As of 2015, the total number of pure family shares in the 41 chaebol firms was only 4.3 per cent, whereas shares by affiliated firms, and related executive members, reached 55.2 per cent (Korea Fair Trade Commission, 2015). This immense control power is achieved through the

\footnotetext{
${ }^{1}$ The Korea Fair Trade Commission defines a chaebol as a group of firms of which more than 30 per cent of shares are owned by the group's controlling shareholders and its affiliated firms.
} 
holdings of the controlling family, and the affiliated firms. Although the owners of family firms, including the chaebol firms, possess the ultimate authority in the firm's decision-making process, they are not burdened with equivalent responsibilities for their managerial decisions. In addition, the controlling power of family members in excess of their cash flow rights, provides them with more means and greater opportunities to expropriate firm resources for their own benefit. Thus, they have the incentives to expropriate other minority investors in the firm by allocating the firm's resources to maximise their own welfare, and to manipulate earnings in order to maintain their control over the firm.

The International Monetary Fund (IMF) and the World Bank noted that dominant family ownership which uses affiliated firms was one of the primary causes of the financial crisis in 1997. It served as the biggest obstacle for improving corporate governance in Korea (Jang, Kim, \& Kim, 2002). The Korean government has also designated that ownershipcontrol disparity is a major cause of the negative impact on firm value and firm performance of Korean firms. In this way, it also propels the ownership-control disparity in the direction of corporate governance for improvement.

Given these unique features of family ownership in Korea, it is interesting to know how family ownership influences earnings quality. In order to reduce information asymmetry between controlling family shareholders and the minority shareholders, a transparent and reliable accounting information is necessary so as to increase earnings quality. When the magnitude of the control-ownership disparity increases, the earnings quality also decreases. It is this occurrence which aggravates the information asymmetry between controlling family shareholders, and the minority shareholders (Kim \& Yi, 2006).

This study investigates the relation between family ownership and firms' earnings quality in the post crisis period of 2000 to 2012. The panel dataset of public firms listed on the Korean Stock Exchange (KSE) were utilised. By using multiple measures of earnings quality and family ownership coupled by the extended test periods, this study aims to expand on previous family ownership researches of Korean firms (An \& Naughton, 2009; An, 2015). This study tests the association between family ownership, and firm value and accruals quality as one proxy of earnings quality. The outcome of this study is able to provide good coverage of the recognised earnings quality indicators and the role of family ownership. Moreover, this study also highlights the substantial differences noted in the earnings quality among the firms within the 
country. It asserts that family ownership of firms is an important determinant of earnings quality, hence extending on previous studies.

This study contributes to the literature in several ways. In order to measure ownership-control disparity, first, it is necessary to grasp what ownership structure means among the controlling shareholders. Prior studies on controlling family ownership in various countries (La Porta et al., 1999, 2000; Claessens et al., 2000; Lemmon \& Lins, 2003; Fan \& Wong, 2002) have not been able to define the term clearly, hence their studies are considered to have limitations in accurately defining the diverse and complex understanding of ownership-control structures. Moreover, most prior studies do not distinguish the controlling shareholders in terms of whether they are internal shareholders or external shareholders. Unlike previous studies looking at family ownership, this study aims to clarify family ownership by classifying it into three measures: one is pure family ownership and the other two are measures of ownershipcontrol disparity - the wedge ratio and the wedge multiplier. These terms were applied by the Korean Fair Trade Commission (hereinafter KFTC) $)^{2}$ to test the different impact of family ownership on earnings quality. Specifically, the wedge multiplier can overcome the problem by not separating the control rights and ownership rights. The wedge multiplier enables the verification of entrenchment effects by controlling the interest alignment effects (Lemmon \& Lins, 2003). Therefore, this study provides additional evidence that will show how family ownership affects earnings quality by precisely placing family ownership into pure family ownership and ownership-control disparity.

Second, the concept of family ownership is predominant in a number of countries, especially in Asian countries where the severe difference between control rights and ownership rights, known as wedge, is an outstanding feature of family ownership. In this regard, the results of this study which highlight the impact of family ownership on earnings quality are relevant for both the Korean context as well as other Asian countries.

Finally, this study extends on previous research by comprehensively exploring the effects of family ownership on four measures of earnings quality - persistence, value-relevance, conservatism and accruals quality. As a proxy of financial reporting quality, earnings

\footnotetext{
2 The KFTC has released data and methods on firm's cash flow rights and voting rights in order to accurately measure ownership-control matrix (the wedge ratio and the wedge multiplier) since 2003.
} 
quality is the primary measure provided in the financial statements (Lev, 1989), which is also the most comprehensive measure for financial reporting quality (Balsam, Krishnan, \& Yang, 2003). Previous studies like Wang (2006) examined the impact of family ownership on earnings quality which was proxied by abnormal accruals, earnings response coefficients and conservatism. Lambert, Jones, Brazel and Showalter (2017) used two measures as proxy for earnings quality - accruals quality and earnings response coefficients while others like Ghani, Santi and Puspitasari (2017) and Liu and Skerratt (2018) added smoothness of earnings. This study expands on Wang's (2006) study by measuring earnings quality based on the fundamental properties of the reported information of the International Financial Reporting Standards (IFRS). According to the IFRS, reported earnings provide useful accounting information for evaluating the firm's performance. It appears that higher quality earnings reflect the firm's reliability and transparency. This represents the primary objective of financial reporting which is to mitigate information asymmetries. Therefore, this study provides a more detailed insight into the role of family ownership in improving earnings quality.

The remainder of this paper is organised as follows. Section 2 reviews previous research and develops the research question. Section 3 outlines the sample, data sources and sampling procedure. Section 4 presents the empirical results and Section 5 concludes the study.

\section{Literature Review and Hypothesis Development}

\subsection{Earnings Quality}

The definition of earnings quality varies according to researchers. Lev (1989) defined earnings quality as the predictive power of the financial variables. McDaniel, Martin and Maines (2002) and Schipper and Vincent (2003) suggested that the IFRS framework is an appropriate framework for evaluating earnings quality as a measure of financial reporting quality. In this study, earnings quality is defined as a proxy of financial reporting quality. It can be assessed through two different approaches: user needs and shareholder/investor protection. This is in tandem with Jonas and Blanchet (2000), based on the fundamental properties of the reported information of the International Financial Reporting Standards (IFRS). The framework of the IFRS states that earnings provide useful accounting information for users to evaluate 
the firm's performance (decision usefulness), and a firm's reliability and transparency represent the higher quality of earnings (accountability). Expanding on the IFRS framework, Jonas and Blanchet (2000) proposed that decision usefulness is linked to the user needs' prospect while accountability is related to shareholder/investor protection's prospect, both reflecting the attributes of earnings quality.

From the user needs' prospect, the purpose of financial statements should provide useful information to users to help them make economic decisions, thereby making a difference to their decisions. Schipper and Vincent (2003) proposed that earnings persistence and value-relevance are derived from a decision usefulness perspective which emphasised on the relevance of financial information. Jonas and Blanchet (2000) proposed that earnings persistence is specifically based on the users' needs since financial reporting users viewed highly persistent earnings as sustainable. This means that earnings are more permanent and less transitory. Barth, Beaver and Landsman (2001) suggested that valuerelevance captures the relevance of earnings which inform present and potential investors in making rational investment decisions. Thus, earnings persistence and value-relevance are referred to as measures of earnings quality from the user needs' prospect.

Under the shareholder/investor protection's prospect, financial information should not mislead or confuse financial information users. It should be fully and fairly disclosed because information asymmetry occurs between management and financial information users. Thus, under the shareholder/investor protection's prospect, earnings quality should emphasise on the reliability or transparency of the financial information. Ball, Kothari and Robin (2000) and Ball, Robin and Wu (2003) asserted that conservatism captures the financial statement transparency while Schipper and Vincent (2003) suggested that accruals quality is consistent with the representational faithfulness perspective. In the context of shareholder/investor protection, earnings quality can be measured by conservatism and accruals quality.

\subsection{Family Ownership}

The relationship between family ownership and earnings quality is explained through two conflicting hypotheses: the alignment hypothesis and the entrenchment hypothesis. Jensen and Meckling (1976), and Fama and Jensen (1983) argued that managerial ownership aligns the interests of owners and managers; it also reduces the agency costs 
which are associated with the separation of decision control when management has reduced ownership in the firm. Demsetz and Lehn (1985) asserted that large shareholders have a stronger and superior oversights' incentive to monitor managers since their wealth is closely linked to the firm's welfare. Families can reduce the agency problem by placing one of their members in the position of a CEO (Anderson, Mansi, \& Reeb, 2003). Since families are long-term investors, they would want to pass the firms to their descendants. Family ownership is stable; it is able to maintain efficient investment strategies which increase firm values. It was observed by Anderson and Reeb (2003) that family firms have significantly better firm performance than non-family firms. This means that family ownership has strong incentives to closely monitor managers; it is also likely to have better information on the firms. These information can be used to reduce firm's cost of debts. Family ownership is also associated with higher earnings quality because family members' interests are better aligned with other shareholders' welfare (Wang, 2006; Ali, Chen, \& Radharkrishnan, 2007). Family ownership also tends to monitor the firm's management more cautiously, thereby supplying higher earnings quality to the financial statement users. This implies that family ownership, as long term investors, has a strong incentive to monitor the management. An (2015) reported that family ownership in Korea positively affects firm value which was measured as ROA, and where Tobin's $Q$ and earnings quality were proxied by accruals quality, decreased firm value, and earnings quality. This is so in the case of the chaebol firms. Liu, Shi, Wilson and Wu (2017) also confirmed Wang's (2006) findings. Their results showed that family firms were less likely to engage in accruals-based earnings management. The positive impact of family ownership is shown even in developed countries. For instance, Eugster (2018) noted that family ownership of Swiss listed firms improved the quality of the firm's information environment because the alignment effect was more likely to dominate the entrenchment effect among family firms. Thus, low agency cost of family ownership leads to a better information environment, resulting in more precise earnings forecasts. Therefore, family ownership has the incentive to produce higher earnings quality, which can be explained by a better alignment of interests between majority and minority shareholders among family firms.

Different arguments (Morck, Shleifer, \& Vishny 1988) have offered the positive effects of family ownership on earnings quality. It was claimed that management entrenchment could occur when insider holdings are high, causing a moral hazard, and the information 
asymmetry problem between insiders (owner-manager) and outside investors (Morck, Shleifer, \& Vishny 1988). Founding families have a strong incentive to ensure that their firms do not pass on to others (Anderson et al. 2003), and for this to happen, most family firms position family members as the firm's CEO or as key members of the management. This practice excludes other more capable and talented outside professional managers. Inadvertently, family firms may hire lower quality management, thereby resulting in lower firm performance. However, altruism may alter the incentive structure of family owned firms, such that many of the agency benefits are offset by moral hazards. It appears that owner management does not help to minimise the agency costs of ownership within family firms (Schulze, Lubatkin, Dino, \& Buchholtz, 2001). Controlling shareholders are generally not willing to lose their control of the firm. The tenacity of control can more closely align the firm's actions with shareholders' own interests. GomezMejia, Nunez-Nickel and Gutierrez (2001) found that family ownership and control were associated with greater managerial entrenchment in Spanish firms. Prencipe and Bar-Yosef (2011) also showed that the impact of board independence on earnings management was weaker in family-controlled companies due to the board control of family members serving as CEOs.

Specifically, in the East Asian emerging-market, a substantial number of firms are owned and managed by controlling families (Claessens et al., 2000). Fan and Wong (2002) suggested that controlling family shareholders in East Asian countries tend to take advantage of flexibility and discretion over accounting choice or auditor selection, so as to distort the firm's true earnings performance. Ball et al. (2003) found that the earnings quality of four East Asian countries (Hong Kong, Singapore, Malaysia and Thailand) were low despite receiving common-law accounting regimes. This outcome was interpreted as controlling family ownership overriding the incentives to report higherquality earnings. Korean studies (Joh, 2003; Kim \& Yi , 2006) showed that a higher control-ownership disparity was prevalent in Korea, thereby exacerbating the agency problem, leading to low firm performance and earnings quality. An and Naughton (2009) also reported that family ownership positively affects firm value, while higher control-ownership disparity was more prevalent in chaebol firms than in non-chaebol firms, thus chaebol firms showed lower firm values and earnings quality.

Chi, Hung, Cheng and Lieu (2015) found that family firms in Taiwan were more likely to engage in earnings management than non- 
family firms. Al-Jaifi (2017) documented that lower earnings quality (high earnings management) signals information, particularly in a higher level of ownership concentration country, like Malaysia. This causes a higher likelihood of expropriating minority shareholders. Tessema, Kim and Dandu (2018) examined how ownership structure of Korean business groups (chaebol firms) affects earnings quality. Similar to this study, they found that chaebol firms have high ownership-control disparity, thereby causing lower earnings quality.

In this regard, it appears that higher earnings quality is determined by the incentives of financial statement preparers (controlling family shareholders or family owner), not by legal/judicial or accounting regimes (Ball \& Shivakumar, 2005). In view of the entrenchment effect of family ownership, as family shareholdings increase, family managers become less constrained by disciplinary forces and more entrenched, therefore, higher family ownership can provide lower earnings quality.

\subsection{Hypotheses Development}

Korean firms are noted for their concentrated share ownerships, affiliated firms and highly diversified business structures. The controlling family shareholders control these firms through a chain of ownership relations (pyramidal ownership). Korean family ownership structures have a significant divergence between control (voting rights) and ownership (cash flow rights) of controlling. This is made possible because there are extensive reciprocal shareholding agreements among member firms. However, there are few mechanisms which can control the discretionary power of the controlling shareholders. Due to the high disparity between cash flow rights and control rights, the controlling shareholders have the incentive and the discretionary power to expropriate minority investors by investing the firm's resources to maximise their own or the group's wealth, even when such investments do not maximise the value of the firm (Bae, Kang, \& Kim, 2002). The effect of the expropriation activities would eventually emerge in the firms accounting earnings and book values, thereby resulting in some disciplinary actions taken by outside investors or by the regulatory bodies. In this regard, controlling family shareholders also have the incentive to hide the firm's true economic performance so as to reduce outsider interference.

Warfield, Wild and Wild (1995) found that high cash flow rights (ownership) reduce earnings management due to the decreased demand 
for accounting-based contracts. This suggests that high family ownership, excluding control via affiliated firms, can positively affect earnings quality. From the perspective of Taiwan, Chu (2011) documented that the positive association is strong, particularly when family members also served as CEOs, top managers, chairpersons, or directors of the firms. This is because family ownership is also combined with active family management and control. Recent Korean studies (Koh \& Park, 2013) have proven the alignment effect of family ownership. Koh and Park (2013) revealed that family firms in which family members also participated in the management, tend to demonstrate lower earnings managements. An (2015) found that pure family ownership, excluding affiliated ownership, mitigates agency problems, thereby improving firm value and earnings quality. Based on the argument above, the following competing hypotheses will be examined.

$\mathrm{H}_{1}$ : Family ownership of Korean firms is systematically associated to earnings quality.

$\mathrm{H}_{1 \mathrm{a}}$ : Pure family ownership of Korean firms is positively associated to earnings quality.

$\mathrm{H}_{1 \mathrm{~b}}$ : The control-ownership disparity of Korean firms is negatively associated to earnings quality.

According to La Porta et al. (1999), large corporations in most wealthy countries have controlling shareholders who enjoy control in excess of their equity holding based on a hierarchical chain of ownership and participation in management. In the context of the Korean economy, the importance of the chaebol business groups, needs no emphasis. A chaebol firm is defined as a gathering of formally independent firms under the single common administrative and financial control of one family. It is a term defined by the Korea Fair Trade Commission (KTFC) as "a group of firms of which more than 30 per cent of shares are owned by the group's controlling shareholders and affiliated firms." Each year, the KFTC ranks chaebol firms according to the size of their total assets, and it only identifies the top 30 groups. This is because the 30 largest chaebol firms account for above 20 per cent of the total output of Korea's GDP. Second, chaebol firms follow the multidivisional organisational structure, under which each individual affiliated firm functions as an operating division. Finally, despite their huge size, chaebol firms are largely family-controlled, with major decisions of the chaebol firms being in the hands of a controlling family rather than professional management. Cross-shareholding enables a few individuals, such as 
the Lee family of the Samsung Group, to tightly control their legally independent firms.

In Korea, the focus of the agency problem is between controlling shareholders and minority shareholders. This is due to the chaebol firms' inherent governance structure. As mentioned above, owner-managers of chaebol firms have every advantage to expropriate other investors in the firm. This agency problem of expropriation is particularly serious when there are few mechanisms available to protect investors, and to control the discretionary powers of the owner-managers. Baek, Kang and Park (2004) analysed the Korean firms during the 1997 financial crisis. They found that chaebol firms with concentrated ownership controlled by family shareholders experienced a larger drop in the value of their equity than firms with less concentrated ownership. This result implies that corporate governance is significantly related to firm value. Thus, differences in corporate governance practice at the firm's level have an important role in determining firm value. An (2015) also found the negative impact of chaebol firms on firm value and earnings quality. He noted that pure family ownership of chaebol firms was significantly lower than non-chaebol firms. Thus, it is concluded that significant affiliated ownership of chaebol firms can result in low firm value and earnings quality. Based on this, the following hypothesis was formulated.

$\mathrm{H}_{2}$ : Family ownership of chaebol is negatively associated to earnings quality

\section{Research Methodology}

\subsection{Sample Selection}

This study uses Korean firms that were listed on the Korean Stock Exchange (KSE) for 13 years (2000-2012). Only non-financial firms were included, hence all the financial institutions (e.g., commercial banks, insurance firms, security brokerage firms) were omitted. This is because the two industries have different accounting methods, format of financial statements, and different regulatory requirements. The financial statements of the non-financial firms, and their stock data required for analysis, were obtained from the OSIRIS and KIS-VALUE databases while the ownership data were manually sourced from the business reports of each firm via the DART system (http:/ / dart.fss.or.kr) provided by the Korean Financial Supervisory Commission (KFSC), the equivalence of the SEC in Korea. The final sample consists of a panel 
data of 489 non-financial Korean firms, and a total of 6,357 firm-year observations, accumulated over the 13-year period. The sample firms being examined are from 10 industry groups classified by the Korean Standard Industry Classification (SIC).

\subsection{Measure of Earnings Quality}

As a proxy of the financial reporting quality, earnings quality can be classified into two categories: 1) user needs, and 2) shareholder/investor protection. From the user needs prospect, earnings quality was measured as persistence and value-relevance while under the shareholder/investor protection's prospect, earnings quality is measured as conservatism and accruals quality. To address the association between earnings quality and foreign investors, earnings quality is set as a dependent variable, following Francis, LaFond, Olsson and Schipper's (2004) methodology.

Since earnings quality is the proxy for user needs, this study measures earnings persistence as the slope-coefficient $\left(\beta_{1}\right)$ estimates of the regression of current earnings on previous earnings. Earnings persistence means how much of the current earnings will persist into the future, and continue from period to period. In order to measure the value-relevance of the accounting information, this study uses Francis et al.'s (2004) methodology where price functions for both earnings and book value of equity. The explanatory power of regression $\left(R^{2}\right)$ was used as the matrix to measure the value-relevance of earnings and book value.

With earnings quality serving as proxy for shareholder/investor protection, this study measured conservatism by using Ball and Shivakumar's (2005) accruals-based test of loss recognition model. Conservatism was thus measured by the incremental coefficient on the association between accruals and negative cash flows. Accruals quality was measured following Dechow and Dichev's (2002) approach. Accruals quality for each firm was thus measured as the absolute value of firm-level residuals $\left(\left|\varepsilon_{i, t}\right|\right)$, from the industry level pooled crosssectional regression of total current accruals on lagged current, and future cash flows plus the change in revenue and gross property, plant, and equipment.

\subsection{Measure of Family Ownership and Wedge}

Family ownership comprises voting rights in the form of cash flow rights, percentage of equity shares directly held by the largest share- 
holder and his/her family as well as the share ownership controlled through the affiliated firms. The Korean National Tax Law states that controlling shareholder ownership is the total number of shares held by the largest shareholder, his/her relatives ${ }^{3}$, specially related persons, and the affiliated firms. The Korean Stock Exchange Law defines the largest shareholder as a person, who together with any specially related persons ${ }^{4}$, holds the largest number of stocks, based on the total number of stocks with voting rights of a firm ${ }^{5}$.

In previous researches, the agency problem between the controlling shareholders (including family and minority shareholder) can be changed by the controlling shareholders' ownership and their ownership-control disparity, such as the wedge ratio (WR) and the wedge multiplier (WM). Based on this, family ownership variables can be classified as: (1) pure family ownership (PUREFAM), and (2) ownership-control disparity (WEDGE).

Pure family ownership (PUREFAM) is the direct ownership of cash flow rights owned by the largest shareholders, and his/her family, excluding stocks held by affiliated firms. The control rights are the sum of the direct ownership, and the indirect shareholding of affiliated firms, which is the controllable share of the controlling shareholder.

Ownership-control disparity (WEDGE) was measured in two ways by the Korean Fair Trade Commission (KFTC) which had been monitoring the ownership-control disparity of chaebol firms since 2003. According to the KFTC, ownership-control disparity was measured as a wedge ratio and a wedge multiplier. The wedge ratio (WR) was calculated as the simple difference between cash flow rights (pure family ownership), and voting rights (family ownership) while the wedge multiplier $(W M)$ was measured as the ratio between voting rights and cash flow rights (family ownership/pure family rights). However, the $W M$ can be excessively large when cash flow rights (denominator) are small. To reduce the disadvantage of the $W M$, the logarithm of the WM was used to complement the WM.

The WR had been used in previous studies (Claessens et al., 2002; La Porta et al., 1999). It was able to show the absolute difference between

\footnotetext{
${ }^{3}$ A spouse, a blood relative within eight degrees of kinship, or an in-law within four degrees of kinship

4 "The major shareholder of the concerned company and that person's spouse and lineal ascendant and descendant; the spouse or lineal ascendant and descendant of an officer of the concerned company."(Article 54-5-(4), Korean Stock Exchange Law)

${ }^{5}$ Article 54-5, Korean Stock Exchange Law.
} 
ownership and control, but it was not able to fully reflect the magnitude of control over ownership. Lemmon and Lins (2003) defined WM as the value of control rights divided by ownership rights. They used it to overcome the limitation of not separating management's control and ownership. This is because it is more important to have control over ownership in the corporate governance structure. The current study subscribes to the KFSC's recommendation and Lemmon and Lins' (2003) approach. Here, ownership-control disparity (WEDGE) was measured as the wedge ratio $(W R)$, and the wedge multiplier (WM). The larger the $W R$ and $W M$ is, the larger the ownership-control disparity will be.

\subsection{Control Variables}

The seven control variables that may affect firm value and earnings quality are: foreign ownership, chaebol group dummy, size, leverage, sales growth ratio, capital asset investment ratio and liquidity ratio. Foreign ownership (FOREIGN) is the percentage of equity shares held by all foreign shareholders as at the end of the year. They are calculated as the total number of shares held by the foreign shareholders and then divided by the total number of shares outstanding. In Korea, the potentially positive impact of foreign ownership, as large outside blockholders, is that it can mitigate family managerial opportunism. Therefore, higher proportions of foreign ownership would induce firms to improve earnings quality, and to decrease opportunistic managerial accounting choices and decisions (An, 2015). To control for size effects, the natural logarithm of the book value of total assets (SIZE) is included as proxy for firm size. Leverage (LEV) is the ratio of the total debts to total assets. Generally, the families of Korean chaebol hold large proportions of shares which may be much less than the majority holdings of the firm. However, they are able to exercise effective control of the firm due to the holdings of the family and their affiliated firms. Therefore, chaebol firms in Korea (listed firms with assets of 5 trillion $\mathrm{KRW})$ are subjected to many government regulations. In keeping with prior Korean studies (Joh, 2003; Kim \& Yi, 2006, Choi, 2007), this study uses size proxy for membership of chaebol firms as a dummy variable [CHAEBOL takes the value of one for firms with asset of 5 trillion KRW (US\$ 4.7 billion) or more; and zero otherwise]. High growth firms are expected to increase earnings quality, but they can be regarded as risky firms which inflated their earnings. To control these offset effects on earnings quality, growth and profitability options are included in 
this study. Growth (GRW) refers to firm's sale growth ratio, measured by annual percentage change of sales. As a measure of profitability, the ratio of net income to total assets (ROA) is employed. Firms with negative earnings (LOSS) is a dummy variable that takes the value of one if the firms' previous year's net income is negative, and zero otherwise.

\subsection{Empirical Model}

This study uses the following equations to test the impact of family ownership on four proxies of earnings quality.

$(\text { Earnings Quality })_{i, t}=\left\{\begin{array}{l}\alpha+\beta_{1}(\text { PUREFAM })_{i, t}+\beta_{2}(\text { FOREIGN })_{i, t}+\beta_{3}(\text { CHAEBOL })_{I, T}+ \\ \beta_{4}\left(\text { PUREFAM }{ }^{*} \text { CHAEBOL }\right)_{I, T}+\zeta_{1}(\text { SIZE })_{i, t}+\zeta_{2}(L E V)_{i, t}+ \\ \zeta_{3}(\text { GRW })_{i, t}+\zeta_{4}(\text { LOSS })_{i, t}+\zeta_{5}(R O A)_{i, t}+\sum_{t=1}^{2001-2012} \psi_{t}(\text { YEAR })_{t}+\varepsilon_{i, t}\end{array}\right.$

$(\text { EarningsQuality })_{i, t}=\left\{\begin{array}{l}\alpha+\beta_{1}(\text { WEDGE })_{i, t}+\beta_{2}(\text { FOREIGN })_{i, t}+\beta_{3}(C H A E B O L)_{I, T}+ \\ \beta_{4}\left(\text { WEDGE }{ }^{*} \text { CHAEBOL }\right)_{I, T}+\zeta_{1}(S I Z E)_{i, t}+\zeta_{2}(L E V)_{i, t}+ \\ \zeta_{3}(G R W)_{i, t}+\zeta_{4}(\text { LOSS })_{i, t}+\zeta_{5}(R O A)_{i, t}+\sum_{t=1}^{2001-2012} \psi_{t}(Y E A R)_{t}+\varepsilon_{i, t}\end{array}\right.$

Since this study utilises panel data, the panel study methodology is considered. According to Himmelberg, Hubbard and Palia (1999) the choice of ownership structure depends on unobserved firm characteristics, such as the contractual, regulatory, or informational environment. With panel data, one common treatment used for this unobserved time-constant effect is the fixed-effect (FE) regression known as the least square dummy variable (LSDV) analysis (Wooldridge 2002; Baltagi 2005). Himmelberg et al. (1999) had suggested that the firm's fixed effect estimators should be used when examining the relationship between ownership and firm performance. The reason is because the crosssectional variation in ownership, which is explained by the unobserved firm heterogeneity, is the firm's fixed effect. However, Zhou (2001) argued that the firm's fixed effect model is not appropriate in this setting since ownership within a firm gradually changes from year to year. In other words, the ownership-firm value relationship is likely to be a cross-sectional phenomenon. 
Extending on Zhou's (2001) argument, the FE estimation is found to be unsuitable for this study for several reasons. First of all, the FE estimation requires a significant variable value within the panel (firm) variations in order for these to produce consistent and efficient estimates. The inclusion of the firm's fixed effects essentially removes most cross-sectional variations of the dependent variable. Therefore, the effect of other explanatory variables (e.g., SIZE, GRW, etc.), may not be observed, unless ownership and board composition measures exhibit substantial time-series variations. This would therefore make the FE estimates imprecise. Second, the FE estimates may aggravate the problem of multicollinearity due to the presence of many dummies, known as LSDV (Baltagi 2005). Third, when the panel dataset (observations on 489 firms over 13 years in this study) consists of large ' $N$ ' (489 firms), and fixed small ' $T$ ' (13 years), the FE estimation becomes inconsistent (Baltagi, 2005). Moreover, for large N, FE estimation would lead to an enormous loss of degrees of freedom (Baltagi, 2005). Fourth, when the sample is extracted from a large population (listed firms on the KSE in this study), individual specific constant terms are regarded as randomly distributed across the cross-sectional firms (Green, 2000). Finally, the general way of choosing between fixed and random effect should be through a Hausman test but this test is not meant to indicate which approach is good, but to show in what way they are different (Black et al. 2009). In addition, Green (2000) has also suggested that a Hausman test becomes problematic when using unbalanced panels, as is the case of this study. Consequently, this study employs the randomeffect regression (RE) as the empirical model.

\section{Results}

\subsection{Descriptive Statistics}

Table 1 shows the descriptive statistics for the variables. As for earnings quality on the user needs, the mean (median) of persistence in the sample was $0.314(0.263)$, and the mean (median) of value-relevance was 0.453 (0.452). Turning to earnings quality on shareholder/investor protection, it appears that conservatism has a mean (median) value of $0.193(0.079)$, and accruals quality has a mean (median) value of $0.076(0.023)$, respectively. The average pure family ownership is 0.206 which is relatively low when compared to other East Asian countries. For example, the average family ownership of Hong Kong was 0.489, 
Table 1: Description of the Samples

\begin{tabular}{llrrrrr}
\hline Categories & Variables & Mean & Median & Min & Max & SD \\
\hline Earnings Quality & PERSISTENCE & 0.314 & 0.263 & -4.634 & 11.188 & 0.703 \\
(User Needs) & VALUE & 0.453 & 0.452 & 0.003 & 0.992 & 0.253 \\
& RELEVANCE & & & & & \\
\hline Earnings Quality & CONSERVATISM & 0.193 & 0.079 & -77.72 & 54.415 & 6.436 \\
(Shareholder/ & ACCRUALS & 0.076 & 0.023 & $1.48 \mathrm{E}-05$ & 3.362 & 0.199 \\
Investor Protection) & QUALITY & & & & & \\
\hline Independent & PUREFAM & 0.206 & 0.203 & 0.0003 & 0.7883 & 0.168 \\
Variables & WR & 0.145 & 0.069 & 0.0007 & 0.887 & 0.177 \\
(Family & WM & 24.069 & 1.243 & 1.000 & 4776.000 & 204.787 \\
Ownership) & Log(WM) & 0.691 & 0.217 & 0.000 & 8.471 & 1.223 \\
\hline Control Variables & FOREIGN & 0.108 & 0.017 & 0.000 & 0.982 & 0.145 \\
& CHAEBOL & 0.084 & 0.0000 & 1.000 & 0.000 & 0.276 \\
& SIZE & 21.230 & 19.430 & 12.922 & 25.890 & 1.456 \\
& LEV & 0.546 & 0.495 & 0.017 & 27.478 & 0.729 \\
& LOSS & 0.229 & 0.000 & 0.000 & 1.000 & 0.412 \\
& GRW & 1.268 & 0.387 & 0.0002 & 288.00 & 6.912 \\
& ROA & 0.014 & 0.036 & -4.724 & 3.599 & 0.231 \\
\hline
\end{tabular}

$\left(\mathrm{Ng}, 2005^{6}\right)$, Singapore was 0.571 (Chau \& Gray, 2002), and Malaysia was 0.430 (Tam \& Tan, 2007). The mean value of the two measures of ownership-control disparity - 'wedge ratio $(W R)^{\prime}$ ' and 'wedge multiplier' $(W M)$ were 0.145 and 24.07, respectively. The supplemented variable of $W M$, the $\log$ of wedge multiplier $(\log (W M))$, has a mean (median) value of 0.691 and 0.217 , respectively, and the standard deviation is much more reduced, when compared to the original WM. Here, foreign investor (FOREIGN) has a mean value of 0.108 , and a median value of 0.017 . The severe difference between mean and median for foreign ownership imply that foreign ownership is concentrated in specific firms. This feature of foreign ownership confirms that foreign shareholders prefer large manufacturing firms with good accounting performance, lower unsystematic risks, and lower leverage firms or underweight, smaller but highly leveraged firms (Kang \& Stulz, 1997).

\footnotetext{
${ }^{6} \mathrm{Ng}$ (2005) use managerial ownership as proxy of family ownership in Hong Kong because the correlation between managerial ownership and family ownership is almost one (0.978).
} 


\subsection{Empirical Results}

Table 2 presents the results generated from the random-effect regression estimates showing the association between earnings quality and the user needs' prospect (e.g., persistence and value-relevance), the shareholder/ investor protection's prospect (e.g., conservatism and accruals quality) and family ownership variables, respectively.

Consistent with the prediction that family ownership and ownership control disparity might affect earnings quality differently, the results show that PUREFAM is positively related to value-relevance $(0.046)$, but is negatively linked with accruals quality $(-0.086)$ at 0.10 and 0.01 levels, respectively. Accordingly, PUREFAM increases earnings quality not only on the user needs' prospects but also on the shareholder/ investor protection's prospects. This result strengthen the alignment effect of family ownership in Korea. However, as for persistence and conservatism measure, PUREFAM is statistically not significant despite consistency with expected signs. Overall, the relation between PUREFAM and earnings quality support the alignment effect of family ownership, thus $\mathrm{H}_{1 \mathrm{a}}$ is accepted. However, more careful efforts could be made to interpret the positive effects of PUREFAM on earnings quality because only two variables (Value-relevance and accruals quality) are statistically significant.

Foreign ownership (FOREIGN) is significantly positive with earnings quality on user needs. The coefficient estimates of FOREIGN on persistence and value-relevance are 0.220 and 0.241 , and at the 0.01 level, respectively. In the association with earnings quality on shareholder/ investor protection, FOREIGN is found to be not statistically significant, both for conservatism and accruals quality. Overall, the relation between FOREIGN and earnings quality support the active monitoring hypothesis of foreign ownership as institutional shareholder. However, the positive impact of FOREIGN on earnings quality would require more detailed interpretations.

With regards to the chaebol firms' variables, the interaction variable with pure family ownership and chaebol firms (PUREFAM*CHAEBOL) as well as chaebol dummy (CHAEBOL) shows significant negative effects with value-relevance and accruals quality, respectively. Rather, the pure family ownership of Korean chaebol firms has negatively impacted earnings quality. According to An (2015), the average of pure family ownership of chaebol firms is 8.52 per cent whereas with nonchaebol firms, the average of pure family ownership reach 26.62 per cent. Therefore, this result can be interpreted as significantly showing 
Table 2: Random Effect Estimation Results for Pure Family Ownership

\begin{tabular}{llccccc}
\hline Variables & & \multicolumn{2}{c}{ User Needs } & \multicolumn{2}{c}{$\begin{array}{c}\text { Shareholder/ } \\
\text { Investor Protection }\end{array}$} \\
\cline { 3 - 4 } \cline { 6 - 7 } & & $\begin{array}{c}\text { Persis- } \\
\text { tence }\end{array}$ & $\begin{array}{c}\text { Value- } \\
\text { Relevance }\end{array}$ & $\begin{array}{c}\text { Conserva- } \\
\text { tism }\end{array}$ & $\begin{array}{c}\text { Accruals } \\
\text { Quality }\end{array}$ \\
\hline Independent & PUREFAM & 0.061 & $0.046^{*}$ & 0.313 & $-0.086^{* * *}$ \\
Variables & & $(1.096)$ & $(1.922)$ & $(1.215)$ & $(-3.151)$ \\
& PUREFAM & 0.010 & $-0.104^{*}$ & & -0.857 & $0.540^{* * *}$ \\
& CHAEBOL & $(0.038)$ & $(-1.991)$ & $(-0.696)$ & $(3.745)$ \\
\hline Control Variables & FOREIGN & $0.220^{* * *}$ & $0.241^{* * *}$ & 0.034 & 0.063 \\
& & $(3.164)$ & $(8.050)$ & $(1.287)$ & $(1.505)$ \\
& CHAEBOL & -0.031 & $-0.136^{* * *}$ & -0.045 & $0.324^{* * *}$ \\
& & $(-0.619)$ & $(-3.975)$ & $(-0.195)$ & $(10.319)$ \\
& SIZE & 0.004 & $-0.009^{* *}$ & $0.082^{* *}$ & $0.034^{* * *}$ \\
& & $(0.443)$ & $(-2.256)$ & $(2.027)$ & $(6.153)$ \\
& LEV & -0.003 & $-0.233^{* * *}$ & $0.182^{* * *}$ & 0.004 \\
& & $(-0.251)$ & $(-4.138)$ & $(2.997)$ & $(0.687)$ \\
& GRW & $0.108^{* * *}$ & $0.036^{* * *}$ & $-0.255^{* * *}$ & $-0.026^{* *}$ \\
& & $(-0.392)$ & $(4.054)$ & $(-2.942)$ & $(-1.996)$ \\
& LOSS & 0.008 & $-0.023^{* *}$ & $0.347^{* * *}$ & 0.016 \\
& & $(0.342)$ & $(-2.229)$ & $(3.056)$ & $(1.468)$ \\
& ROA & 0.391 & $-0.061^{* * *}$ & 0.326 & -0.028 \\
& & $(-1.465)$ & $(1.956)$ & $(-0.410)$ & $(-1.134)$ \\
\hline Constant & & -0.001 & $0.689^{* * *}$ & -1.267 & $-0.618^{* * *}$ \\
& & $(-0.006)$ & $(6.185)$ & $(-1.631)$ & $(-5.873)$ \\
\hline Model Fits & Adj R ${ }^{2}$ & $0.018^{* * *}$ & $0.042^{* * *}$ & $0.026^{* * *}$ & $0.158^{* * *}$ \\
& F-Statistics & 6.154 & 14.790 & 8.957 & 52.237 \\
\hline
\end{tabular}

Note:

(EarningsQuality $)_{i, t}=\left\{\begin{array}{l}\alpha+\beta_{1}(\text { PUREFAM })_{i, t}+\beta_{2}(\text { PUREFAM } * \text { CHAEBOL })_{i, t}+\beta_{3}(\text { FOREIGN })_{t, T}+\beta_{4}(\text { CHAEBOL })_{i, t} \\ +\zeta_{1}(\text { SIZE })_{i, t}+\zeta_{2}(\text { LEV })_{i, t}+\zeta_{3}(\text { GRW })_{i, t}+\zeta_{4}(\text { LOSS })_{i, t}+\zeta_{5}(\text { ROA })_{i, t}+\sum_{t=1}^{2001-2012} \psi_{t}(\text { YEAR })_{t}+\varepsilon_{i, t}\end{array}\right.$

Subscripts $i$ denotes individual firms, $t$ time period. The dependent variable Earnings Quality is for four measures of earnings quality: 1) Persistence, 2) Value-Relevance, 3) Conservatism, and 4) Accruals Quality. PUREFAM is the percentage of equity shares owned by the largest personal shareholder and his/her families. FOREIGN is the percentage of equity shares held by foreign investors. CHAEBOL is a dummy variable which takes the value of one for firms with asset of 5 trillion KRW (US\$4.7 billion) or more; and zero otherwise. Firm size (SIZE) is the natural log of the total assets. Leverage $(L E V)$ is total debt scaled by total assets. Growth prospects $(G R W)$ is market to book ratio of equity. Firm with negative earnings (LOSS) is a dummy variable that takes the value of one if firm's previous year's net income was negative, and zero otherwise. Profitability $(R O A)$ is return on assets. YEAR is a time dummy. Superscripts ${ }^{*},{ }^{* *}$ and ${ }^{* * *}$ indicate statistical significance at $10 \%, 5 \%$ and $1 \%$ levels, respectively ( $t$-statistics). 
that low pure family ownership of chaebol firms causes lower earnings quality. Although this study finds the negative effect of pure family ownership of chaebol firms on value-relevance and accruals quality, hypothesis $\mathrm{H}_{2}$ is accepted.

Tables 3 and 4 indicate the results of ownership-control disparity (WEDGE) on earnings quality. Inconsistent with prior Korean studies (Joh, 2003), the coefficients of both WR and WM are statistically insignificant with persistence and conservatism. Thus, the impact of higher ownership-control disparity on firm value is weak and insignificant. Interestingly, ownership-control disparity positively affected valuerelevance and accruals quality. The coefficients of WR and WM on value-relevance are statistically significant and positive at the 0.05 and 0.10 levels, respectively. In the association with accruals quality, the coefficients of WR on accruals quality are statistically significant and negative $(-0.036)$ at the 0.10 level. This result is also inconsistent with prior Korean studies (Joh, 2003, Kim \& Yi, 2006) which highlight that high affiliated ownership increase firm's earnings management (measured as discretionary accruals). This is because affiliated ownership provides controlling shareholders with more incentives and opportunities to hide adverse consequences of their self-serving behaviours.

The inconsistent results of this study can be interpreted in two ways. First, internal shareholders (controlling family shareholders) have a higher predictability of firm's financial information since information asymmetry exists between internal shareholders, and external shareholders (minority shareholders). For example, if the firm's prospects are bright, internal shareholders would increase their ownership and if otherwise, they would lower their ownership. Accordingly, it can be assumed that the greater the firm has with a larger ownership-control disparity, the higher the earnings quality. This is achieved by reducing the agency costs between the internal and external shareholders since the controlling shareholders also facilitate the monitoring, supervision and containment of the management. Second, ownership-control disparity of non-chaebol firms with positive effects of WEDGE on earnings quality is more prevalent in chaebol firms. In this study, the mean value of WR of chaebol firms is 24.87 per cent $^{7}$ while the mean value of WR of non-chaebol firms is 14.05 per cent ${ }^{8}$. Accordingly, the WR of chaebol

\footnotetext{
${ }^{7}$ As of 2007, WR of chaebol firms had increased to 31.28 per cent (KFTC).

${ }^{8}$ In addition, mean value of pure family ownership (cash flow rights) of chaebol firms was 7.37 per cent, while that of non-chaebol firms was 20.63 per cent.
} 
Table 3: Random Effect Estimation Results of Wedge Ratio

\begin{tabular}{|c|c|c|c|c|c|}
\hline \multirow[t]{2}{*}{ Variables } & & \multicolumn{2}{|c|}{ User Needs } & \multicolumn{2}{|c|}{$\begin{array}{l}\text { Shareholder/ } \\
\text { Investor Protection }\end{array}$} \\
\hline & & $\begin{array}{l}\text { Persis- } \\
\text { tence }\end{array}$ & $\begin{array}{c}\text { Value- } \\
\text { Relevance }\end{array}$ & $\begin{array}{l}\text { Conserva- } \\
\text { tism }\end{array}$ & $\begin{array}{c}\text { Accruals } \\
\text { Quality }\end{array}$ \\
\hline \multirow[t]{3}{*}{$\begin{array}{l}\text { Independent } \\
\text { Variables }\end{array}$} & $W R$ & $\begin{array}{c}-0.066 \\
(-1.259)\end{array}$ & $\begin{array}{l}0.047^{* *} \\
(2.051)\end{array}$ & $\begin{array}{c}0.578 \\
(1.501)\end{array}$ & $\begin{array}{r}-0.036^{*} \\
(-1.908)\end{array}$ \\
\hline & $W R^{*}$ & 0.052 & $-0.139^{*}$ & $-1.24^{* *}$ & $0.179^{*}$ \\
\hline & CHAEBOL & $(0.291)$ & $(-1.812)$ & $(-2.368)$ & (1.760) \\
\hline \multirow[t]{13}{*}{ Control Variables } & FOREIGN & $\begin{array}{l}0.217^{* * *} \\
(3.217)\end{array}$ & $\begin{array}{l}0.231^{* * *} \\
(7.673)\end{array}$ & $\begin{array}{c}-0.294 \\
(-1.124)\end{array}$ & $\begin{array}{c}0.059 \\
(1386)\end{array}$ \\
\hline & CHAEBOL & -0.046 & -0.024 & $-1.639^{* * *}$ & $0.294^{* * *}$ \\
\hline & & $(-0.821)$ & $(0.991)$ & $(-5.075)$ & (8.552) \\
\hline & SIZE & 0.004 & $-0.011^{* * *}$ & $0.105^{* *}$ & $0.037^{* * *}$ \\
\hline & & $(0.514)$ & $(-2.853)$ & (2.575) & $(6.406)$ \\
\hline & LEV & -0.005 & $-0.024^{\star * *}$ & $0.185^{\star * *}$ & 0.004 \\
\hline & & $(-0.404)$ & $(-4.287)$ & (3.068) & $(0.755)$ \\
\hline & GRW & $0.108^{* \star *}$ & $0.032^{\star \star *}$ & $-0.252^{\star \star \star}$ & $-0.027^{\star *}$ \\
\hline & & (5.798) & $(4.015)$ & $(-2.903)$ & $(-2.026)$ \\
\hline & LOSS & 0.003 & $-0.025^{* *}$ & $0.347^{\star * *}$ & $0.019^{*}$ \\
\hline & & (0.119) & $(-2.350)$ & $(3.082)$ & (1.665) \\
\hline & $R O A$ & -0.073 & $-0.059^{* \star \star}$ & 0.311 & -0.027 \\
\hline & & $(-1.486)$ & $(-2.796)$ & (1.359) & $(-1.089)$ \\
\hline \multirow{2}{*}{\multicolumn{2}{|c|}{ Constant }} & 0.012 & $0.738^{* * *}$ & $-1.697^{* *}$ & -0.677 \\
\hline & & $(0.070)$ & (10.321) & $(-2.206)$ & $(-6.229)$ \\
\hline Model Fits & Adj $R^{2}$ & $0.018^{* * *}$ & $0.042^{* * *}$ & $0.027^{* * *}$ & $0.142^{* * *}$ \\
\hline \multicolumn{2}{|l|}{ F-Statistics } & 6.197 & 14.833 & 9.456 & 46.967 \\
\hline
\end{tabular}

Note:

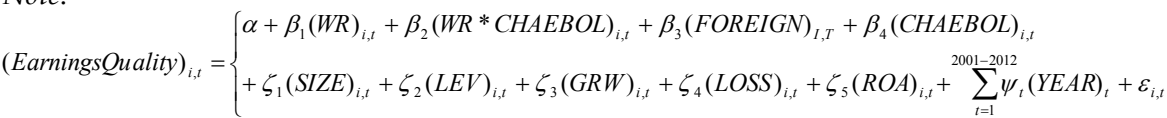

Subscripts $i$ denotes individual firms, $t$ time period. The dependent variable Earnings Quality is for four measures of earnings quality: 1) Persistence, 2) Value-Relevance, 3) Conservatism, and 4) Accruals Quality. WR is wedge ration, the difference between family ownership and pure family ownership. FOREIGN is the percentage of equity shares held by foreign investors. CHAEBOL is a dummy variable which takes the value of one for firms with asset of 5 trillion KRW (US\$4.7 billion) or more; and zero otherwise. Firm size (SIZE) is the natural log of the total assets. Leverage ( $L E V)$ is total debt scaled by total assets. Growth prospects (GRW) is market to book ratio of equity. Firm with negative earnings (LOSS) is a dummy variable that takes the value of one if firm's previous year's net income was negative, and zero otherwise. Profitability (ROA) is return on assets. YEAR is a time dummy. Superscripts *,** and *** indicate statistical significance at $10 \%, 5 \%$ and $1 \%$ levels, respectively ( $t$-statistics). 
Table 4: Random Effect Estimation Results of Wedge Multiplier

\begin{tabular}{|c|c|c|c|c|c|}
\hline \multirow[t]{2}{*}{ Variables } & & \multicolumn{2}{|c|}{ User Needs } & \multicolumn{2}{|c|}{$\begin{array}{c}\text { Shareholder/ } \\
\text { Investor Protection }\end{array}$} \\
\hline & & $\begin{array}{l}\text { Persis- } \\
\text { tence }\end{array}$ & $\begin{array}{c}\text { Value- } \\
\text { Relevance }\end{array}$ & $\begin{array}{l}\text { Conserva- } \\
\text { tism }\end{array}$ & $\begin{array}{c}\text { Accruals } \\
\text { Quality }\end{array}$ \\
\hline $\begin{array}{l}\text { Independent } \\
\text { Variables }\end{array}$ & $\begin{array}{l}\text { WM } \\
W M^{*} \\
\text { CHAEBOL }\end{array}$ & $\begin{array}{l}8.91 \mathrm{E}-05 \\
(1.107) \\
-5.30 \mathrm{E}-05 \\
(-0.528)\end{array}$ & $\begin{array}{l}\text { 6.23E-05* } \\
(1.796) \\
-1.81 \mathrm{E}-07 \\
(-0.004)\end{array}$ & $\begin{array}{l}-0.005 \\
(-1.367) \\
6.72 \mathrm{E}-06 \\
(0.015)\end{array}$ & $\begin{array}{l}-1.72 \mathrm{E}-05 \\
(-0.346) \\
7.99 \mathrm{E}-05 \\
(1.489)\end{array}$ \\
\hline Control Variables & $\begin{array}{l}\text { FOREIGN } \\
\text { CHAEBOL } \\
\text { SIZE } \\
\text { LEV } \\
\text { GRW } \\
\text { LOSS } \\
\text { ROA }\end{array}$ & $\begin{array}{c}0.205^{* *} \\
(2.351) \\
-0.021 \\
(-0.414) \\
0.029 \\
(0.287) \\
-0.005 \\
(-0.313) \\
0.095^{* * *} \\
(4.926) \\
0.011 \\
(0.408) \\
-0.034 \\
(-0.468)\end{array}$ & $\begin{array}{c}0.274^{* * *} \\
(7.301) \\
-0.015 \\
(-0.713) \\
-0.009^{*} \\
(-1.944) \\
-0.026^{* * *} \\
(-3.257) \\
0.027^{* * *} \\
(3.274) \\
-0.021^{*} \\
(-1.701) \\
-0.035 \\
(-1.113)\end{array}$ & $\begin{array}{c}-0.174 \\
(-0.123) \\
0.039 \\
(0.168) \\
0.091^{*} \\
(1.935) \\
0.127 \\
(1.517) \\
-0.222^{* *} \\
(-2.498) \\
0.380^{* * *} \\
(2.933) \\
0.113 \\
(0.341)\end{array}$ & $\begin{array}{c}0.010 \\
(0.249) \\
0.239^{* * *} \\
(7.601) \\
0.046^{* * *} \\
(6.421) \\
-0.001 \\
(-0.193) \\
-0.026^{* *} \\
(-2.221) \\
0.004 \\
(0.405) \\
-0.087^{* * *} \\
(-3.007)\end{array}$ \\
\hline Constant & & $\begin{array}{c}0.035 \\
(0.179)\end{array}$ & $\begin{array}{l}0.701^{* * *} \\
(8.431)\end{array}$ & $\begin{array}{l}-1.479 * \\
(-1.667)\end{array}$ & $\begin{array}{l}-0.836^{* * *} \\
(-6.1554)\end{array}$ \\
\hline $\begin{array}{l}\text { Model Fits } \\
\text { F-Statistics }\end{array}$ & $\operatorname{Adj} R^{2}$ & $\begin{array}{l}0.016^{\star * *} \\
4.452\end{array}$ & $\begin{array}{l}0.042^{* * *} \\
11.977\end{array}$ & $\begin{array}{l}0.027^{* * *} \\
7.564\end{array}$ & $\begin{array}{l}0.098^{* * *} \\
24.816\end{array}$ \\
\hline
\end{tabular}

Note:

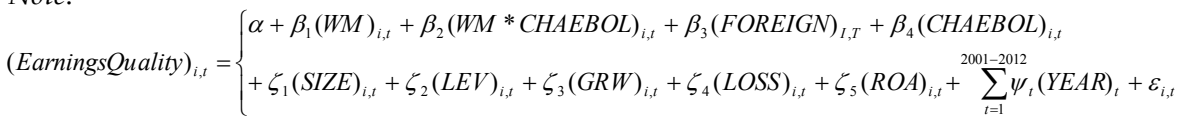

Subscripts $i$ denotes individual firms, $t$ time period. The dependent variable Earnings Quality is for four measures of earnings quality: 1) Persistence, 2) Value-Relevance, 3) Conservatism, and 4) Accruals Quality. WM is wedge multiplier, calculated by family ownership divided by pure family ownership. FOREIGN is the percentage of equity shares held by foreign investors. CHAEBOL is a dummy variable which takes the value of one for firms with asset of 5 trillion KRW (US\$4.7 billion) or more; and zero otherwise. Firm size (SIZE) is the natural log of the total assets. Leverage (LEV) is total debt scaled by total assets. Growth prospects (GRW) is market to book ratio of equity. Firm with negative earnings (LOSS) is a dummy variable that takes the value of one if firm's previous year's net income was negative, and zero otherwise. Profitability (ROA) is return on assets. YEAR is a time dummy. Superscripts * ${ }^{* *}$ and ${ }^{* * *}$ indicate statistical significance at $10 \%, 5 \%$ and $1 \%$ levels, respectively ( $t$-statistics). 
groups is much larger, and this indicates that control via affiliated ownership is less significant in non-chaebol firms. Thus, hypothesis $\mathrm{H}_{1 \mathrm{~b}}$ is not accepted. The same applied for the pure family ownership (PUREFAM), where $W R$ is also significant with value-relevance and accruals quality. Nevertheless, the rejection of $\mathrm{H}_{1 \mathrm{~b}}$ must be interpreted with more caution.

As expected, the coefficients of interaction on ownership-control disparity and chaebol firms and chaebol dummy are negatively significant with value-relevance and conservatism, but positively significant with accruals quality at the 0.01 level. Thus, it can be said that Korean chaebol firms negatively impact earnings quality even after the Asian financial crisis. This confirms the findings of Kim and Yi (2006) and An (2015). Overall, the ownership-control disparity results of chaebol firms are quite similar to those of the pure family ownership of chaebol firms, as noted in Table 2. This therefore, indicates that controlling family ownership of chaebol firms have a dominant influence on firms using affiliated ownership. Although hypothesis $\mathrm{H}_{2}$ is accepted, it should be interpreted with more caution too because WR showed a significantly positive effect on two proxies of earnings quality - value-relevance and accruals quality.

Further, the relation between FOREIGN and earnings quality is noted to be significantly positive with persistence and value-relevance, but negative with conservatism. This finding therefore, endorses the observation that foreign shareholders do not efficiently monitor the firm's management. Other control variables are not substantially different from those presented in Table 2. In general, the results can be deduced to be consistent with the expectations.

The disadvantage of WM has been discussed in section 3.3 and WM can be excessively large when cash flow rights (denominator) are small. Thus, this study conduct an additional test by using the logarithm of $W M$ as a complement. Table 5 indicates that the overall result is almost similar to those shown in Table 4 . However, the interaction variable $\left(\log (W M)^{*} C H A E B O L\right)$ is noted to be significant with accruals quality at 0.10 level. In addition, the negative impact of $C H A E B O L$ on accruals quality is also noted to be significantly strong at 0.01 level. This result therefore, highlights the robustness of the entrenchment effect for chaebol firms. It also confirms that large ownership-control disparity reduces earnings quality, especially for shareholder/investor protection. Thus, hypothesis $\mathrm{H}_{2}$ is accepted. 
Table 5: Random Effect Estimation Results of the log Wedge Multiplier

\begin{tabular}{|c|c|c|c|c|c|}
\hline \multirow[t]{2}{*}{ Variables } & & \multicolumn{2}{|c|}{ User Needs } & \multicolumn{2}{|c|}{$\begin{array}{c}\text { Shareholder/ } \\
\text { Investor Protection }\end{array}$} \\
\hline & & $\begin{array}{l}\text { Persis- } \\
\text { tence }\end{array}$ & $\begin{array}{l}\text { Value- } \\
\text { Relevance }\end{array}$ & $\begin{array}{l}\text { Conserva- } \\
\text { tism }\end{array}$ & $\begin{array}{c}\text { Accruals } \\
\text { Quality }\end{array}$ \\
\hline $\begin{array}{l}\text { Independent } \\
\text { Variables }\end{array}$ & $\begin{array}{l}\log (W M) \\
\log (W M)^{*} \\
C H A E B O L\end{array}$ & $\begin{array}{c}-7.61 \mathrm{E}-05 \\
(-0.008) \\
0.011 \\
(0.558)\end{array}$ & $\begin{array}{c}0.007^{*} \\
(1.794) \\
0.002 \\
(0.226)\end{array}$ & $\begin{array}{c}-0.065 \\
(-1.501) \\
0.006 \\
(0.951)\end{array}$ & $\begin{array}{c}-8.63 \mathrm{E}-05 \\
(-0.018) \\
0.018^{*} \\
(1.892)\end{array}$ \\
\hline Control Variables & $\begin{array}{l}\text { FOREIGN } \\
\text { CHAEBOL } \\
\text { SIZE } \\
\text { LEV } \\
\text { GRW } \\
\text { LOSS } \\
\text { ROA }\end{array}$ & $\begin{array}{c}0.225^{* *} \\
(2.571) \\
-0.035 \\
(-0.580) \\
0.006 \\
(0.062) \\
-0.008 \\
(-0.459) \\
0.095^{* * *} \\
(4.930) \\
0.011 \\
(0.396) \\
-0.014 \\
(-0.186)\end{array}$ & $\begin{array}{l}0.038^{* * *} \\
(7.328) \\
-0.016 \\
(-0.623) \\
-0.010^{* *} \\
(-2.258) \\
-0.026^{* * *} \\
(-3.347) \\
0.001 \\
(0.089) \\
-0.021^{*} \\
(-1.701) \\
-0.029 \\
(-0.927)\end{array}$ & $\begin{array}{c}-2.027^{* * *} \\
(-5.050) \\
0.014 \\
(0.168) \\
0.103^{* *} \\
(2.159) \\
0.133 \\
(1.583) \\
-0.064^{* *} \\
(-0.950) \\
0.377^{* * *} \\
(2.899) \\
0.076 \\
(0.227)\end{array}$ & $\begin{array}{c}0.019 \\
(0.450) \\
0.176^{* * *} \\
(5.411) \\
0.033^{* * *} \\
(5.021) \\
0.003 \\
(0.560) \\
-0.001 \\
(-0.233) \\
0.010 \\
(1.105) \\
-0.027^{* * *} \\
(-0.974)\end{array}$ \\
\hline Constant & & $\begin{array}{c}0.085 \\
(0.436)\end{array}$ & $\begin{array}{l}0.728^{* * *} \\
(8.677)\end{array}$ & $\begin{array}{l}-1.678^{*} \\
(-1.874)\end{array}$ & $\begin{array}{l}-0.582^{* * *} \\
(-4.6634)\end{array}$ \\
\hline Model Fits & $\begin{array}{l}\text { Adj } \mathrm{R}^{2} \\
\text { F-Statistics }\end{array}$ & $\begin{array}{l}0.015^{* * *} \\
(4.296)\end{array}$ & $\begin{array}{l}0.035^{* * *} \\
(10.105)\end{array}$ & $\begin{array}{l}0.023^{* * *} \\
6.534\end{array}$ & $\begin{array}{l}0.080^{* * *} \\
19.726\end{array}$ \\
\hline
\end{tabular}

Note:

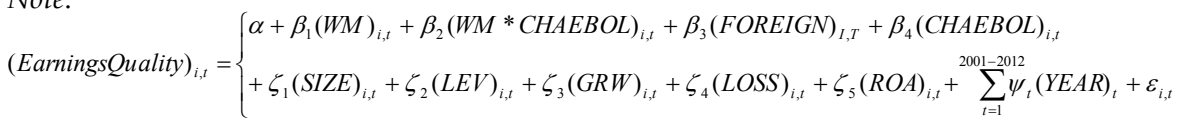

Subscripts $i$ denotes individual firms, $t$ time period. The dependent variable Earnings Quality is for four measures of earnings quality: 1) Persistence, 2) Value-Relevance, 3) Conservatism, and 4) Accruals Quality. $\log (W M)$ is the logarithm of wedge multiplier, calculated by $\log$ (family ownership divided by pure family ownership). FOREIGN is the percentage of equity shares held by foreign investors. $C H A E B O L$ is a dummy variable which takes the value of one for firms with asset of 5 trillion KRW (US\$4.7 billion) or more; and zero otherwise. Firm size (SIZE) is the natural log of the total assets. Leverage $(L E V)$ is total debt scaled by total assets. Growth prospects $(G R W)$ is market to book ratio of equity. Firm with negative earnings (LOSS) is a dummy variable that takes the value of one if firm's previous year's net income was negative, and zero otherwise. Profitability $(R O A)$ is return on assets. YEAR is a time dummy. Superscripts ${ }^{*},{ }^{* *}$ and ${ }^{* * *}$ indicate statistical significance at $10 \%, 5 \%$ and $1 \%$ levels, respectively ( $t$-statistics). 


\section{Conclusion}

This study examines the impact of family ownership on firm value and earnings quality by using panel data listed on the Korean Stock Exchange (KSE) over the 2000 to 2012 period. Specifically, this study employs two different measures of family ownership: pure family and two proxies of ownership-control disparity, the wedge ratio and the wedge multiplier. Unlike prior studies using the wedge ratio as the sole measure of ownership-control disparity, this study incorporates the wedge multiplier element even though it might exaggerates the ownership-control disparity. Lemmon and Lins (2003) mentioned that the wedge multiplier has the advantage to overcome the problem of the wedge ratio by not separating control rights and ownership rights. Thus, the use of the wedge multiplier is expected to verify the entrenchment effects with the control of interest alignment effects. The current study has also provided comprehensive results to show how family ownership influences earnings quality by using three types of family ownership variables and four proxies of earnings quality.

This study has found that family ownership increases earnings quality in non-chaebol firms. The effect of ownership-control disparity (Wedge) on earnings quality positively affect value-relevance and accruals quality. The findings confirm that family ownership in Korea support the alignment effects and that Korean chaebol firms show low earnings quality because of significantly lower pure family ownership and larger ownership-control disparity. This is also consistent with prior Korean studies (An, 2015). Controlling family shareholders of chaebol firms dominate their firms by using affiliated ownership, thus, significant ownership-control disparity of chaebol firms aggravate the entrenchment effects. Control via affiliated ownership is significant in chaebol firms because the ownership-control disparity of chaebol firms is about 10 per cent above that of non-chaebol firms. Through the tests conducted for chaebol firms, the negative impact of ownership-control disparity on earnings quality is confirmed.

This study has also found that foreign ownership is only significant with user needs' earnings quality (persistence and value-relevance). This indicates that foreign shareholders play a restrictive role in monitoring the firms. This may be attributed to the fact that as large outside blockholders, foreign shareholders act as transient investors without any significant incentive to monitor firm management.

This study has also provided new evidence to show the impact of family ownership on firm value and earnings quality. Many East- 
Asian studies (Fan \& Wong, 2002; Claessen et al., 2002; Ball et al., 2000, 2003) have suggested that family ownership decreases firm's value and earnings quality because controlling families dominate the firm at all levels of the firm's decision-making processes; they also override the incentives to report higher-quality earnings, thereby expropriating outside shareholders' wealth. However, the current study finds that family ownership is better aligned with the firms, thus higher family ownership increases earnings quality.

This study bears management and academic implications. The managements of chaebol firms or large business groups should try to improve the transparency and quality of their financial reporting. Market participants should be recognised for their incentives to do earnings management. Family firms which are very prevalent in emerging markets are significantly associated with earnings quality, and this should prompt analysts and investors to consider further valuations.

Nonetheless, as is relevant in all studies, this study also bears some limitations. First, this study has assumed a linear impact of family ownership. Prior research (Demsetz, 1983) had suggested that an increase in insider shareholding (family shareholding) could increase management entrenchment. Thus, future research should seek to identify a non-linear relationship between family ownership and earnings quality. Second, four proxies of earnings quality were used, but they do not necessarily reflect all aspects of the earnings quality. This study shows that the results between family ownership and earnings quality are mixed as a result of using the four proxies. Thus, future studies may consider looking at the association between corporate governance and earnings quality. Finally, the outcome drawn of family ownership as provided by this study cannot be equated as saying that most of the hypotheses are contradictory or that the opposite hypotheses have been theoretically and empirically studied. It is important and necessary to consider carefully whether the ownership-control disparity can be an indicator of the negative influence of family ownership.

\section{References}

Al-Jaifi, H.A. (2017). Ownership concentration, earnings management and stock market liquidity: Evidence from Malaysia. Corporate Governance, 17(3), 490510. http://dx.doi.org/10.1108/CG-06-2016-0139

Ali, A., Chen, T-Y., Radharkrishnan, S. (2007). Corporate disclosures by family firms. Journal of Accounting and Economics, 44(1-2), 238-286. http://dx.doi. org/10.1016/j.jacceco.2007.01.006 
An, Y. (2015). The impact of family ownership on firm value and earnings quality: Evidence from Korea. International Business Management, 9(4), 625636.

An, Y., \& Naughton, T. (June, 2009). The impact of family ownership on firm value and earnings quality: Evidence from Korea. Paper presented at the European Financial Management Association Conference, Milan.

Anderson, R.C., Mansi, S.A., \& Reeb, D.M. (2003). Founding family ownership and agency cost of debt. Journal of Financial Economics, 68(2), 263-285. http://dx.doi.org/10.1016/S0304-405X(03)00067-9

Anderson, R.C., \& Reeb, D.M. (2003). Founding family ownership and firm performance: Evidence from the S\&P 500. The Journal of Finance, 58(3), 13011328. http://dx.doi.org/10.1111/1540-6261.00567

Bae, K.H., Kang, J.K., \& Kim, J.M. (2002). Tunneling or value added? Evidence from mergers by Korean business groups. The Journal of Finance, 57(6), 2695-2740. http://dx.doi.org/10.1111/1540-6261.00510

Baek, J-S., Kang, J.K., \& Park, K.S. (2004). Corporate governance and firm value: Evidence from the Korean financial crisis. Journal of Financial Economics, 71(2), 265-313. http://dx.doi.org/10.1016/S0304-405X(03)00167-3

Ball, R., Kothari, S.P., \& Robin, A. (2000). The effect of international factors on properties of accounting earnings. Journal of Accounting and Economics, 29(1), 1-51. http:// dx.doi.org/10.1016/S0165-4101(00)00012-4

Ball, R., Robin, A., \& Wu, J.S. (2003). Incentives versus standards: properties of accounting income in four East Asian countries. Journal of Accounting and Economics, 36(1-3), 235-270. http:// dx.doi.org/10.1016/j.jacceco.2003.10.003

Ball, R., \& Shivakumar, L. (2005) Earnings quality in UK private firms: Comparative loss recognition timeliness. Journal of Accounting and Economics, 39(1), 83-128. http://dx.doi.org/10.1016/j.jacceco.2004.04.001

Balsam, S., Krishnan, J., \& Yang, J.S. (2003). Auditor industry specialization and earnings quality. Auditing: A Journal of Practice and Theory, 22(2), 71-97. http://dx.doi.org/10.2308/aud.2003.22.2.71

Baltagi, B.H. (2005). Econometric analysis of panel data (3rd ed.). Hoboken, NJ: John Wiley \& Sons.

Barth, M.E., Beaver, W.H., \& Landsman, W.R. (2001). The relevance of the value relevance literature for financial accounting standard setting: Another view. Journal of Accounting and Economics, 31(1-3), 77-104. http://dx.doi. org/10.1016/S0165-4101(01)00019-2

Black, B.S., Kim, W., Jang, H., \& Park, K.S. (2010). How corporate governance affects firm value: Evidence on channels from Korea (working paper). Seoul, South Korea: Korea University.

Chau, G.K., \& Gray, S.J. (2002). Ownership structure and corporate voluntary disclosure in Hong Kong and Singapore. The International Journal of Accounting, 37(2), 247-265. http://dx.doi.org/10.1016/S0020-7063(02)00153-X

Chi, C.W., Hung, K., Cheng, H.W., \& Lieu, P.T. (2015). Family firms and earnings management in Taiwan: Influence of corporate governance. 
International Review of Economics \& Finance, 36(March), 88-98. http:/ /dx.doi. org/10.1016/j.iref.2014.11.009

Choi, J.S. (2007) Changes in the forecast relevancy, persistence, and valuation relevancy of earnings components between before and after the financial crisis. Accounting and Auditing Research, 45, 237-276.

Chu, W. (2011) Family ownership and firm performance: Influence of family management, family control, and firm size. Asia-Pacific Journal of Management, 28(4), 833-851. http://dx.doi.org/10.1007/s10490-009-9180-1

Claessens, S., Djankov, S., \& Lang, L.H.P. (2000). The separation of ownership and control in East Asian corporations. Journal of Financial Economics, 58(12), 81-112. http://dx.doi.org/10.1016/S0304-405X(00)00067-2

Claessens, S., Djankov, S., Fan, J.P.H., \& Lang, L.H.P (2002). Disentangling the incentive and entrenchment effects of large shareholdings. The Journal of Finance, 57(6), 2741-2771. http://dx.doi.org/10.1111/1540-6261.00511

Dechow, P.M., \& Dichev, I.D. (2002). The quality of accruals and earnings: The role of accrual estimation errors. The Accounting Review, 77(s-1), 35-59.

Demsetz, H. (1983). The structure of ownership and the theory of the firm. The Journal of Law and Economics, 26(2), 375-390. http://dx.doi.org/10.1086/ 467041

Demsetz, H., \& Lehn, K. (1985). The structure of corporate ownership: Causes and consequences. Journal of Political Economy, 93(6), 1155-1177. http:// dx.doi.org/10.1086/261354

Eugster, N. (2018). Family firms and financial analyst activity. Pacific-Basin Finance Journal, 57(October). http:/ / dx.doi.org/10.1016/j.pacfin.2018.03.002

Fama, E.F., \& Jensen, M.C. (1983). Agency problems and residual claims. The Journal of Law and Economics, 26(2), 327-349. http://dx.doi.org/10.1086/ 467038

Fan, J.P.H, \& Wong, T.J. (2002). Corporate ownership structure and the informativeness of accounting earnings in East Asia. Journal of Accounting and Economics, 33(3), 401-425. http:/ /dx.doi.org/10.1016/S0165-4101(02) 00047-2

Francis, J., LaFond, R., Olsson, P.M., \& Schipper, K. (2004) Costs of equity and earnings attributes. The Accounting Review, 79(4), 967-1010. http://dx.doi. org/10.2308/accr.2004.79.4.967

Gomez-Mejia, L.R., Nunez-Nickel, M., \& Gutierrez, I. (2001). The role of family ties in agency contracts. Academy of Management Journal, 44(1), 81-95. http://dx.doi.org/10.5465/3069338

Green, W.H. (2000). Econometric analysis (4th ed.). Upper Saddle River, NJ: Prentice Hall.

Himmelberg, C.P., Hubbard, R.G., \& Palia, D. (1999). Understanding the determinants of managerial ownership and the link between ownership and performance. Journal of Financial Economics, 53(3), 353-384. http://dx.doi. org/10.1016/S0304-405X(99)00025-2

Jang, J., Kim, W., \& Kim, K. (2002). Valuation effect of accounting opacity of Korean companies. Korea: The Korea Economic Research Institute. 
Jensen, M.C., \& Meckling, W.H. (1976). Theory of the firm: Managerial behavior, agency costs and ownership structure. Journal of Financial Economics, 3(4), 305-360. http://dx.doi.org/10.1016/0304-405X(76)90026-X

Joh, S.W. (2003). Corporate governance and firm profitability: Evidence from Korea before the economic crisis. Journal of Financial Economics, 68(2), 287322. http:/ / dx.doi.org/10.1016/S0304-405X(03)00068-0

Jonas, G.J., \& Blanchet, J. (2000) Assessing quality of financial reporting, Accounting Horizons 14(3), 353-363. http:/ / dx.doi.org/10.2308/acch.2000. 14.3.353

Jung, K., \& Kwon, S.Y. (2002). Ownership structure and earnings informativeness: Evidence from Korea. The International Journal of Accounting, 37(3), 301-325. http://dx.doi.org/10.1016/S0020-7063(02)00173-5

Kang, J.K., \& Stulz, R.M. (1997) Why is there a home bias? An analysis of foreign portfolio equity ownership in Japan. Journal of Financial Economics, 46(1), 3-28. http:// dx.doi.org/10.1016/S0304-405X(97)00023-8

Kim, J-B., \& Yi, C.H. (2006). Ownership structure, business group affiliation, listing status, and earnings management: Evidence from Korea. Contemporary Accounting Research 23(2), 427-464. http://dx.doi.org/10.1506/7T5B72FV-MHJV-E697

Koh, Y.S., \& Park, S.Y. (2013). The participation of family members in the business management and family firms management. The Korean Accounting Journal, 22(2), 61-109.

The Korean Fair Trade Commission. (2015). Shareholding statistics of crossshareholding restricted firms in 2015. Sejong, Korea: KFTC.

Korea Economic Research Institute. (2016). Trend and economic analysis of business group ownership and control. Seoul, Korea: Author.

La Porta, R., Lopez-de-Silanes, F., \& Shleifer, A. (1999). Corporate ownership around the world. The Journal of Finance, 54(2), 471-517. http://dx.doi. org/10.1111/0022-1082.00115

La Porta, R., Lopez-de-Silanes, F., Shleifer, A., \& Vishny, R.W. (2000). Agency problems and dividend policies around the world. The Journal of Finance, 55(1), 1-33. http://dx.doi.org/10.1111/0022-1082.00199

Lambert, T.A., Jones, K.L., Brazel, J.F., \& Showalter, D.S. (2017). Audit time pressure and earnings quality: An examination of accelerated filings. Accounting, Organizations and Society, 58(April), 50-66. http://dx.doi. org/10.1016/j.aos.2017.03.003

Lemmon, M.L., \& Lins, K.V. (2003). Ownership structure, corporate governance, and firm value: Evidence from the East Asian financial crisis. The Journal of Finance, 58(4), 1445-1468. http:// dx.doi.org/10.1111/1540-6261.00573

Lev, B. (1989). On the usefulness of earnings and earnings research: Lessons and directions from two decades of empirical research. Journal of Accounting Research, 27, 153-192. http:// dx.doi.org/10.2307/2491070

Lim, U., \& Kim, C.S. (2005). Determinants of ownership structure: An empirical study of the Korean conglomerates. Pacific-Basin Finance Journal, 13(1), 1-28. http://dx.doi.org/10.1016/j.pacfin.2003.11.001 
Liu, M., Shi, Y., Wilson, C., \& Wu, Z. (2017). Does family involvement explain why corporate social responsibility affects earnings management? Journal of Business Research, 75(June), 8-16. http://dx.doi.org/10.1016/j. jbusres.2017.02.001

Liu, S., \& Skerratt, L. (2018). Earnings quality across different reporting regimes: Listed, large private, medium-sized, small and micro companies in the UK. Journal of Applied Accounting Research, 19(1), 2-19. http://dx.doi. org/10.1108/JAAR-02-2015-0009

McDaniel, L., Martin, R.D., \& Maines, L.A. (2002). Evaluating financial reporting quality: The effects of financial expertise vs. financial literacy. The Accounting Review, 77(s-1), 139-167. http://dx.doi.org/10.2308/accr. 2002.77.s-1.139

Morck, R., Shleifer, A., \& Vishny, R.W. (1988). Management ownership and market valuation: An empirical analysis. Journal of Financial Economics, 20 (JanuaryMarch), 293-315. http://dx.doi.org/10.1016/0304-405X(88)90048-7

$\mathrm{Ng}$, C.Y.M. (2005). An empirical study on the relationship between ownership and performance in a family-based corporate environment. Journal of Accounting, Auditing \& Finance, 20(2), 121-146. http://dx.doi.org/10.1177/ 0148558X0502000202

Prencipe, A., Bar-Yosef, S. (2011) Corporate governance and earning management in family-controlled companies, Journal of Accounting, Auditing and Finance, 26, 199-227. http:/ /dx.doi.org/10.1177\%2F0148558X11401212

Ghani, E.K, Santi, M., \& Puspitasari, E. (2017). Analysis of unconditional conservatism and earnings quality on financial reporting practices in Indonesia upon IFRS Convergence. Management \& Accounting Review, 16(1), 75-88.

Schipper, K., \& Vincent, L. (2003). Earnings quality. Accounting Horizons, 17 (Supplement), 97-110.

Shleifer, A., \& Vishny, R.W. (1986). Large shareholders and corporate control. Journal of Political Economy, 94(3), 461-488. http://dx.doi.org/10.1086/ 261385

Schulze, W.S., Lubatkin, M.H., Dino, R.N., \& Buchholtz, A.K. (2001). Agency relationships in family firms: Theory and evidence. Organization Science, 12(2), 99-116. http:// dx.doi.org/10.1287/orsc.12.2.99.10114

Tam, O.K., \& Tan, M.G.S. (2007). Ownership, governance and firm performance in Malaysia. Corporate Governance: An International Review, 15(2), 208-222. http://dx.doi.org/10.1111/j.1467-8683.2007.00555.x

Tessema, A., Kim, M.S., \& Dandu, J. (2018). The impact of ownership structure on earnings quality: The case of South Korea. International Journal of Disclosure and Governance, 15(3), 129-141. http://dx.doi.org/10.1057/s41310018-0039-x

Wang, D. (2006). Founding family ownership and earnings quality. Journal of Accounting Research, 44(3), 619-656. http://dx.doi.org/10.1111/j.1475-679X. 2006.00213.x 
Warfield, T.D., Wild, J.J., \& Wild, K.L. (1995). Managerial ownership, accounting choices, and informativeness of earnings. Journal of Accounting and Economics, 20(1), 61-91. http:// dx.doi.org/10.1016/0165-4101(94)00393-J

Wooldridge, J.M. (2002). Econometric analysis of cross-section and panel data. Cambridge, Massachusetts \& London: MIT Press.

Zhou, X. (2001). Understanding the determinants of managerial ownership and the link between ownership and performance: Comment. Journal of Financial Economics 62(3), 559-571. http://dx.doi.org/10.1016/S0304$405 X(01) 00085-X$ 